\title{
The Key Role to Improve CSR Performance: A Case Study of New Holland: Punjab
}

Effulgence

Vol. 16 No. 1 (Special Issue 2)

January - June, 2018 Rukmini Devi Institute of Advanced Studies

E-mail : effulgence@rdias.ac.in, Website : www.rdias.ac.in

http://effulgence.rdias.ac.in/user/default.aspx

https://dx.doi.org/10.33601/effulgence.rdias/v16/iSpl2/2018/47-53

\author{
Ms. Saloni Chaudhary ${ }^{1}$ \\ Dr. Raghavendra G. Rao ${ }^{2}$
}

\begin{abstract}
Corporate Social Responsibility (CSR) is a new advance strategy of the corporate sector to develop a sustainable business in the market. After the amended companies act, 2013 in India, it's mandatory for all corporate and non-corporate sectors to participate in CSR activities. For the remarkable sustainable growth of companies, adopt new advanced technology to maintain a balance between social, economic and environment. Companies integrate some policies, plan, and programmers' for sustainable growth in the future.

The purpose of this paper understands the role of New Holland in CSR activities. After the amendment 2013, company law. Every corporate sector contributes in CSR by spending their some percent of profit. New Holland spends 3\% of their annual profit on CSR activities. To ascertain their amount reach to NGOs, Stakeholder for CSR, and descry they are actually working for social, economic, and environmental welfare, this paper focuses on Corporate Social Responsibility done by New Holland agriculture farm industries.

New Holland spends 3\% of their profit for CSR. People received all facilities for providing to improve their social, environmental, and economic level. People aware of basic benefits provided government through corporate sector. They stand for their basicneed.
\end{abstract}

Keywords: Corporate Social Responsibility, Stake holder, NGOs, Sustainability development..

\section{INTRODUCTION}

or the corporate sector, CSR (Corporate Social
Responsibility) is a tool for promoting their contribution to social, economic and environmental welfare. In modern world corporate retaining their confidence by participates in CSR activities in the external environment. CSR is also known as the corporate world where an organization takes initiatives to influence their activities on their employee, the social area nearby environment as well as the stakeholder. Organization comes forward to take responsibility their employee and nearby area people improve their lifestyle at the social level. For this, they make some policies to run the program for up gradation of CSR activities. Stakeholders play

1. Ph.D Research Scholar, SRM University, Sonepat (Haryana) India, salonichaudhary140@gmail.com

2. H.O.D Environmental Science, SRM University, Sonepat (Haryana) India, raghavgrao@gmail.com 
a considerable role in organization and society. All programs run according to with policy norm it should depend upon the honesty of stakeholders because the organization could not be linked directly with society; it should be linked to the stakeholders. In fact, organization given amount to stakeholder for improvement of society and environment. At global level CSR agenda begins on peak level the late 1900s it changes the strategy of the market, it was new era globalization between economy, society, and environment. Every organization participates in CSR actives to promote their business strategy.

In India, all corporate sectors participate in CSR activities for the improvement of the backward section of society like education, health, basic skill development (D.S. Prathima). In India, CSR is not a recent concept it has had a tradition concept only the criteria of CSR activities has been changing from time to time. Since last 19th century, CSR activities increased by corporate as well as government sector (Jayati Sarkar et al,.). The concept of CSR is more important when it covers area sustainable development. It means India come forward under the light when it did its CSR activities with sustainable development manner (Kavita D. Chordiya). This is a conceptual theory for developing nation. Organization for maintaining its image in society work on a triple bottom line of people, planet, and profit (Nidhi Sharma).

People: Organization business practices towards people beneficial. It must be needed organization doing work for the support of socially sustainable development.

Planet: nominated to our surrounding environment. There is a vice-versa relationship between organization and environment. If the organization does not harm the environment, environment reacts same for them. If organization harm the environment to produce toxic wastage, environment harm community by natural disaster it will affect both organizations as well as society. So organization must not be harmful to the environment.
Profit: create an organization to reduce the input material cost. It is the valuable thing for all organizations. Profit must be increased by the wellorganized management. If management works properly definitely organization goes on profit graph figure high.

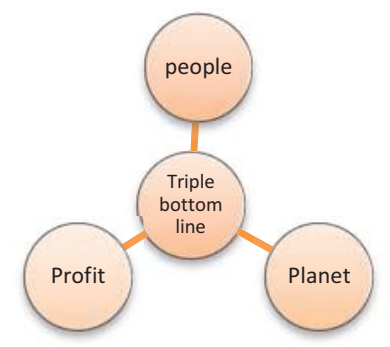

\section{Figurer1. Represent connectivity of three variable people, profit and planet.}

Source: Self create by author.

Now, Indian companies occur in top 10 companies in the Asian companies by showing grow rate in its profitable manner and also, participate in Corporate Social activities. The organization cannot grow in a sustainable manner without play leading role in Corporate Social Responsibility. The organization focuses on below poverty line people of society maintains their living standard by providing necessary things like food, drinking water, education, employment. For the maximum goal of companies expected more for their stakeholder side work with honest by using found to valuable thing for society. Sometimes we have seen for the rapid growth of an organization, it degrades the environment by producing toxic waste material in the environment, these types of industries not work in a sustainable manner. They show high growth rate in short period of time after that its growth rate graph decrease due to dislike community people. It should be mandatory organization work with environmental norms.

\section{Role of Companies Act, 2013 in India}

Under the Section 135 and Schedule VII for company Act 2013, for the condition to companies participate in Corporate Social Responsibilities (CSR). This 
company Act 2103 regulate after 1 April 2014. According, to this Act Private public, all corporate sector participate in CSR activities. Corporate sector sending $2 \%$ of their net annual turnover profit percentage and this contribution immediately addon for three financial years. Profit and loss of the companies described under Section 381(1) a and Section 198 of 2013 Act. Activities under Corporate Social Responsibility (CSR) full fill by company like: providing food for hungry people or demolish hunger rate from below poverty line people, provide drinking water, education, sanitation source, employment, gender equality, economic support for backward group of society, maintain sustainable environmental for living, providing funds for sports activities, Art and heritage sites and national government and non-government research institution. By all these activities help to grow nation economic growth rate of the nation.

In India national and foreign companies, both occur. The criteria of Corporate Social Responsibility (CSR) both for same. Foreign companies will obey the rules. According to the company Act 2013, organizations constitute a board for CSR activities and in this board, three directors occur one is independent and another two are dependent. The company must be registered with trust for doing CSR activities. For a foreign company, they will do work for CSR activities with two directors. Companies do not spend more than $5 \%$ profit on an annual turnover to CSR activities. All these norms companies no need to disclose on their official website. Company Act 2013 decided what kind of company undertaken in it. Some companies are exempted to perform Corporate Social Responsibility activities.

\section{DEFINATION OF CSR:}

According to an author:

"For the improvement business strategy of corporate sector improve the quality of work for social level"

"CSR define as collaboration of three-word economy, environment, and social run together for the improvement of human being welfare"'"

Some famous definition of CSR

According to European Commission, it described "for established their business company associated with social and environmental activities with the unforced manner with their stakeholder".

According to Forbes 2010 described "the interaction between the company and social community work on vice-versa. The company did Corporate Social responsibilities activities for social community people, people must aware about the company and promote its product and services help the increase their sale".

Now-a-days various companies adopting Corporate Social Responsibility for their social status improvement. For their benefit mostly companies' runs Corporate Social responsibilities practices and such type of benefits is:

1. Corporate Social Responsibility running by attuning strong bond between stakeholder and corporate because CSR activities not directly held by corporate it would be running stakeholder. By this, a strong relationship develops between corporate and stakeholder.

2. The company participates in Corporate Social Responsibility by this involvement number of investor generate.

3. Create a sustainable work environment.

4. Corporate Social responsibility improves status and reputation of the organization. Corporate participate in CSR activities help protect then boycott action.

5. By Corporate Social, Responsibilities increase the management power of organization.

\section{BACKGROUND OF THE STUDY}

The economic value of nation mostly depends upon the business strategy. Every organization tries to 
achieve profit in a sustainable manner. Shareholder participation in the organization increases their economic growth rate. Increase number of the organization increases the rate of interest in Corporate Social Responsibility activity by performing economic, environment and social level.

According to Prime Minister Dr. Manmohan Singh, "Corporate Social Responsibility is done all about taxpaying strategy. Rather than it should be done by rule and regulation of Indian government on the organization. Business organization volunteers' motivate its intrinsic value for collaborating its profitable amount for human welfare. According to the survey of research organization corporate sector involved in CSR activities more than the Indian Public and government sector. Our recent prime minister Jan Dhan Yojna defines as every citizen if Indian must involve in increasing the financial system of India. Now, it's defined as "MAKE IN INDIA" mainly focus on stimulating business strategy at the level of people generate its own business at Small Medium Enterprises level (www.pmindia.gov.in).

\section{Factor promoting CSR activities:}

1. Raising the trade of GLOBALIZATION by multinational and national companies focus on CSR concern to the improvement of human resource management and environmental protection.

2. For the development of social reform corporate and non-corporate sector making bond together.

3. By the help of advanced communication technology easy to detect the CSR activities.

4. Companies take more interest in human and environment issues. To regulate CSR activities, increasing the awareness of legislation government limits.

\section{OBJECTIVES:}

1. To know the CSR activities concept and CSR befits in Punjab.
2. To study the current status CSR in Punjab.

3. To study the efforts by New Holland in CSR activities to improve the lifestyle of a backward section of society.

\section{RESEARCH METHODOLOGY}

A case study to regulate the Corporate Social Responsibility activities of Case New Holland $(\mathrm{CNH})$ it's an agricultural farm implement manufacturing organization. The primary data of organization collected by area manager of Punjab Mr. Parshant Singh Arya and CBU manager Mr. Rachpal Singh and secondary data collected by organization websites, reports, journal, article, books etc.

\section{Limitations:}

1. Primary data collected only by Area Manager and CBU Manager of Punjab head office located in Mohali (Punjab), not by the country head office located Greater Noida (U.P).

2. For determined the Corporate Social Responsibility practices have actually done by the organization is confirmed by taking interview of Sarpach, gram panchayat and Sale person of the organization of the Village not by the survey filled the questionnaire for an individual person of the village.V. Research methodology

\section{Company profile}

New Holland completes its 100 years of innovation the first time it was found in Pennsylvania by Abe Zimmerman in 1895 (Carlo Lambro). In 1917, it was made first big agricultural machinery Ford tractor built before it at their starting phase of agriculture machinery manufacturing it was built some level agricultural implements. Now Case New Holland $(\mathrm{CNH})$ is a global brand by manufacturing agricultural machinery, construction machinery, bus, truck, and train as well. According to International Financial Reporting Standard (IFRS) EU preparing a report as issued by International Accounting 
Standard Board (IASB) Case New Holland (CNH) having 12 brands in agricultural and commercial sector having 64 manufacturing plant in worldwide having 50Research and Development Centers in worldwide having 64000 employees on role and offrole of organization service at globally Case New Holland has served it services in 180 countries. Case New Holland diverse its business with the economic decision for social and environmental development in long-term by fabricating bond together with stakeholder. It also works on regional sustainability development by creating a regional officer to track the practice's impact on the social and environmental level.

\section{Case New Holland in India}

Case New Holland has a first time established in India 1998 by the name of ford group. Now, it's a leading agriculture company in India by naming of New Holland Fait India (NHFI). In India manufacturing unit Case New Holland has plant making 40,000 to 50,000 tractors annually which are transported in all over India and worldwide (www.newhollandindia.com). Since the time established they sold 300,000 in across India and abroad. Case New Holland has the first time launched $70 \mathrm{Hp}$ (horsepower) tractor after that, they make low horsepower tractor as according to need of Indian farmers (www.agriculture1newholland.com). Case New Holland has provided all facilities to farmers beginning of crop sowing to till harvesting time of crop with the help of wide range of implements like a tractor, harvesting combine, tillage, mowers, chopper, cotton picker, biomass solution, sugarcane harvester etc.

\section{Study Area:}

In this paper, we have taken Punjab as a study area. Area of Punjab is 50,362 or1.53 of the total geographical area of India. According to sesus2011 total population of Punjab is 27,704,236 (www.Wikipedia.org). Punjab is a land of agriculture it is also called by name "GRANARY OF
INDIA" Total agricultural land of Punjab is $7848 \mathrm{sqkm}$ and income obtain by agriculture is 16.78 (GROSS) and 17.65\% (NET) in 2014-2015. The GDP of Punjab is 3.17 lakh corers (www.punjabgov.nic.in).

\section{Case New Holland practices in Punjab:}

New Holland has success full to full fill the requirement of society by doing the following practices in Corporate Social Responsibilities

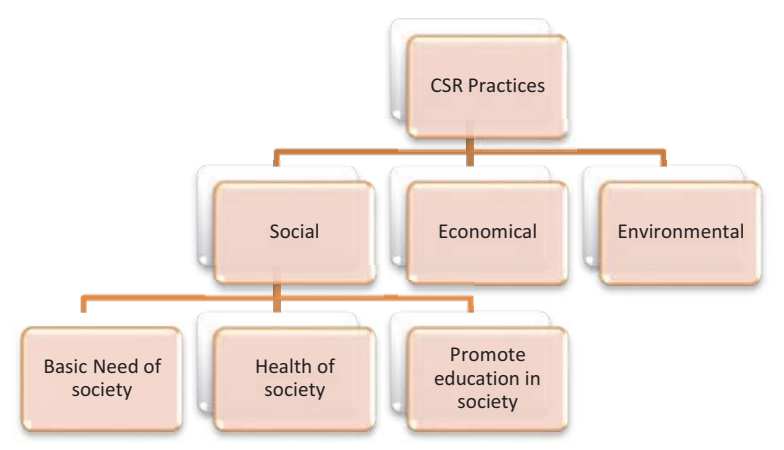

Figurer2. Represent flowchart of connectivity Corporate Social Responsibility with each variable. Source: Self create by an author.

\section{Activities of New Holland on social level}

- New Holland Committee board mainly focus on the rural area for social development.

- Finishing the rate of hunger from a rural area.

- Providing food to below poverty line people to decrease the rate of malnutrition by this, they are trying to save more and more people, children to protect by diseases which occur mainly by malnutrition.

- Under the SWACH BHARAT mission which runs by our present Prime Minister Sh. Narendra Modi, New Holland Provide sanitation facilities to the rural area.

- Providing drinking water by the water-cooler.

- New Holland has run are the various project they are trying to give education to rural area people.

- Promoting the value of education through 
seminars, they are trying to promote education and understand the value of an education to be uneducated people.

- By running educational camps they are trying to improve the vocational skill of children.

- By making old age homes providing facilities to a senior citizen living freely.

- By shows, some add, advertisement and play they are trying to understand the people about gender equality.

- They trying to finish caste system. They promote equality between social economy and social uneconomical people.

- They give some financial help the armed force family.

- New Holland runs some programs for protection of heritage site, historical building, art galleries etc.

- New Holland promotes sport for the rural area, motivate people to regard sports.

- New Holland contributes to prime minister “NATION RELIEF FUND" and Research and Development Center.

\section{Activities of New Holland on economic level}

- Remove the poverty form rural area to give an opportunity for people for jobs.

- For doing social welfare practices people aware of the product of industries by this sale increase, it will automatically increase the economic growth rate of the industry.

- If the industry economic rate increased due to this economic rate of the country should be increased.

- For creating new job opening providing facilities to increase employment.

\section{Activities of New Holland on environmental level}

- New Holland has work on the sustainable manner which one is safe for the environment.

- Promoting the value of flora and fauna by advertisement.

- Promoting to perverse natural resources. Doing work based on clean energy by making bio-fuel engine.

- New Holland participates in "SWACH GANGA ABHIYAN" by giving some fund.

- Protect the environment by various type of pollution main one air pollution.

All these Corporate Social responsibilities are done by New Holland undertook the part of their Net profit of annual turnover, it should not below than $2 \%$.

As we described above there are common Corporate Social Responsibility activities for allover Punjab, but additionally, they fully adopt a village Kaller Majra in Patiala district. In this village, all activities like cultural, social, environmental and economical are done by New Holland. They spend one corer rupees on the development this village.

Following activities perform by New Holland in Kaller Majra village:

- In this Patiala district, belt farmer grows Rice, wheat, and sugarcane as a crop. The main this is that farmer choose to burn the stubble residues after harvesting the crop due to this large amount of "AIR POLLUTION" cause during harvesting period of time. New Holland gives them such kinds of agriculture machinery one time in thrice year help the prevent our environment by burning of crop residue. This machinery makes cube of crop residue and sold it into the thermal plant to make electricity. New Holland gives baler, tractor, cutter, trolley all these implements cost 35lakh. Farmer obeys government rule to prevent the environment from air pollution.

- New Holland provides projectors to make smart classroom in a government school.

- New Holland distributes school uniform and notebook to all children of the village.

- New Holland installs water-cooler for drinking purpose in school and commercial area of the village. 
- New Holland runs free service camp of agricultural implements for farmers.

- New Holland runs free health checkup camp once in a week with specialist doctor team.

- New Holland provides facilities to farmer learn driving agriculture machinery by free of cost.

\section{CONCLUSION}

As increasing the number of corporate industries, Corporate Social Responsibility Practices increasing as well. Moreover, organization work on business strategy with social and environmental. It will automatically increase its economic market. Nowadays corporation is determinate to him-selves towards socially responsible because of their stakeholder solve the society relative issue they are the most relevant to them. A stakeholder is also a part of society. If society and environment are affected organization habitat it will be automatically affecting to stakeholder as well. There are two key factors which affect the sustainable economic growth of the organization. One is an intrinsic factor: in this factor employee satisfaction, higher quality productivity rate, more requirement opening for youth. Second, factor: in this factor stakeholder for taking responsibility social and environmental level, is organization satisfied the social community it will automatically increase in its customer percentage, investors. Both intrinsic and extrinsic factor work on the win-win situation.

New Holland plays a vital role to full fill all requirements of social as well as the environmental region. It performs various activities for improving the skill of farmers by organized various type of camp, fair and special training in the plant. New Holland organized every Saturday, short training for dealer and farmer to improve their skill related to agricultural machinery it will generate a great trust of a farmer on the organization. Further, it will help to increasing the number of customers.

At last Social responsibility and economic rate of organization work on regression factor, if one be increased another one automatically increased.

\section{REFERENCES}

1) Carlo Lambro, Investor day Auburn hills annual report May 8th 2014 New Holland Agriculture.

2) D.S. Prathima, Proceedings of the Second European Academic Research Conference on Global Business, Economics, Finance and Banking (EAR15Swiss Conference) ZurichSwitzerland, 2015. ISBN: 978-1-63415-477-2. 3-5 July, 2015 Paper ID: Z5100.

3) Jayati Sarkar and Subrata Sarkar, Corporate Social Responsibility in India - An Effort to Bridge the Welfare Gap, Indira Gandhi Institute of Development Research (IGIDR) General Arun Kumar Vaidya Marg Goregaon (E), Mumbai400065, INDIA. WP-2015-023.

4) Kavita D. Chordiya, "Corporate Social Responsibilities of Mahindra \& Mahindra", Assistant Professor Dr. B.V. Hiray College of Management \& Research Centre, Malegaon Camp (Nasik), IOSR Journal of Business and Management (IOSR-JBM) e-ISSN: 2278-487X, pISSN: 2319-7668 PP 14-20.

5) Nidhi Sharma, A synopsis "An empirical study of Corporate Social Responsibility practices in India in changing global scenario and its impact on companies profitability" Dayalbagh educational institute (Deemed university) Dayalbagh, Agra. September, 2013.

6) www.pmindia.gov.in/en/pms-profile accessed on February 23, 2018 at 9pm.

7) www.newhollandindia.com, accessed on February 24, 2018 at 1pm.

8) www.agriculture1newholland.com, accessed on February 20,2018 at 10pm.

9) www.wikipedia.org/wiki/punjab_India, accessed on 24 February, 2018 at 11pm.

10) www.punjabgov.nic.in, accessed on 24 February, 2018 at $11.30 \mathrm{pm}$. 